\title{
Akumulasi Regangan di Sumatera Berdasarkan Data Pengamatan GPS Tahun 2002-2008 dan Dampak Kerusakan Lingkungan Akibat Pelepasan Regangan
}

\author{
Riko Maiyudi ${ }^{1}$, Irwan Meilano ${ }^{2}$, Dina Sarsito ${ }^{2}$ \\ ${ }^{1}$ Jurusan Teknik Geodesi, Fakultas Teknik Sipil dan Perencanaan, ITENAS, Bandung \\ ${ }^{2}$ Jurusan Teknik Geodesi dan Geomatika, Fakultas Ilmu dan Teknologi Kebumian, \\ ITB-Bandung \\ Email: rikomaiyudi88@gmail.com
}

\begin{abstract}
ABSTRAK
Pulau Sumatera terletak di antara dua lempeng tektonik yaitu lempeng Indo-Australia dan lempeng Eurasia. Intensitas gempa bumi sangat besar di pulau ini, terutama di sepanjang daerah pesisir barat. Pada 2002-2008 periode, banyak gempa bumi besar yang menyebabkan korban jiwa dan kerusakan lingkungan. Fenomena ini menunjukkan bahwa studi tentang pola deformasi pulau Sumatera sangat diperlukan. Studi yang diperlukan adalah untuk rencana mitigasi bencana di masa depan. Pola deformasi gempa dapat diamati dengan GPS pengamatan (Global Positioning System). Data yang digunakan untuk gempa Sumatera adalah GPS Sumatera Array (SuGAr). Perangkat lunak yang digunakan untuk data Array GPS Sumatera dari pulau Sumatera adalah Gamit 10.4. Dari hasil pengolahan data, dapat disimpulkan bahwa data perpindahan koordinat stasiun dapat digunakan jika data outlier telah terhapus. Dari koordinat perpindahan stasiun bisa diperoleh vektor perpindahan semua stasiun sebelum, selama atau setelah gempa bumi. Dari perpindahan nilai-nilai vektor, nilai regangan yang terjadi di sepanjang pulau Sumatera dapat diperkirakan. Dari data regangan, nilai akumulasi regangan 2002-2008 dapat diperoleh. Sehingga dapat dianalisis wilayah yang berpotensi terjadinya gempa selanjutnya.
\end{abstract}

Kata Kunci : Akumulasi Regangan, Deformasi, Kerusakan Lingkungan,

\begin{abstract}
The Sumatra Island is located between two tectonic plates; the Indo-Australia Plate and the Eurasian plate. The intensity of the earthquakes is very large on the island because of this, especially along the western coastal area. On the 2002 to 2008 period, many large earthquakes that caused casualties and damage to the environment. These phenomena shows that the studies of the deformation patterns of the Sumatra island is required. The studies are required for disaster mitigation plans in the future. The deformation patterns of the earthquake can be observed with GPS (Global Positioning System) observation. The data that is being used for Sumatra earthquake is the Sumatran GPS Array. The software that is used for the Sumatran GPS Array data of the Sumatra Island is the Gamit 10.4. From the data processing, it can be concluded that there are displacements of the nations can be used if the outlier data has been erased. From the station displacement coordinates, we can obtain the displacement vector of all of the station before, during or after the earthquakes. From the displacement vector values, the values of the strain that occurs along the Sumatra Island can be estimated. From the strain data, the accumulated value of strain from 2002 to 2008 can be obtained. Finally it can be predicted potential area for next earthquake.
\end{abstract}

Keywords: Keywords: Deformation, Environmental Damage, Accumulated Strain. 


\section{PENDAHULUAN}

Lempeng Eurasia dan Indo-Australia merupakan dua lempeng yang mengapit pulau Sumatera dengan kecepatan pergeseran lempeng Indo-Australia sekitar $6 \mathrm{~cm}$ per tahun yang bergerak ke arah utaratimur laut [5].

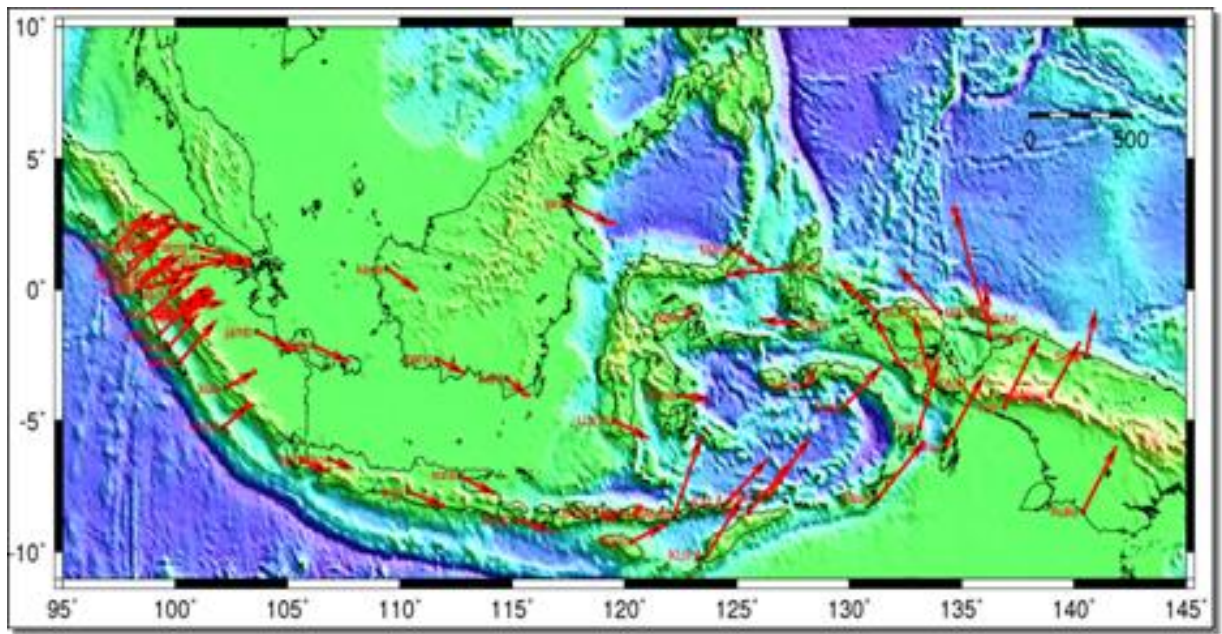

Gambar 1. Peta Tektonik Aktif di Indonesia [2]

Dengan letak geografis pulau Sumatera yang berada pada pertemuan dua lempeng di atas, mengakibatkan intensitas gempa sangat besar di sepanjang pulau Sumatera khususnya di sepanjang pantai barat pulau Sumatera. Hal ini dapat dilihat dari jumlah gempa yang terjadi sepanjang tahun 2002-2008 yang terekam oleh pusat pemantauan gempa dunia di bawah naungan United States Geological Survey (USGS) yang terletak di Colorado [7]. Berikut data gempa yang diperoleh dari data USGS sepanjang tahun 2002-2008 yang berisi 13 gempa besar dengan kekuatan di atas $6 \mathrm{Mw}$ pada Tabel 1 berikut ini:

Tabel 1. Daftar gempa yang terjadi di Sumatra dari tahun 2004 - 2008 [7]

\begin{tabular}{|c|c|c|c|c|c|c|}
\hline No & Tanggal & $\begin{array}{c}\text { Waktu } \\
(\mathrm{UTC}+7)\end{array}$ & Lokasi & Koordinat & $\begin{array}{c}\text { Kedalaman } \\
(\mathrm{km})\end{array}$ & Magnitude \\
\hline 1 & 20 -Feb-08 & $15: 08: 30$ & Simeulue & $\begin{array}{c}2.768^{\circ} \mathrm{N} \\
95.964^{\circ} \mathrm{E}\end{array}$ & 26 & 7.4 \\
\hline 2 & $24-$ Feb-08 & $21: 46: 21$ & Kepulauan Mentawai & $\begin{array}{c}2.405^{\circ} \mathrm{S} \\
99.931^{\circ} \mathrm{E}\end{array}$ & 22 & 6.5 \\
\hline 3 & 25 -Feb-08 & $15: 36: 33$ & Kepulauan Mentawai & $\begin{array}{c}2.486^{\circ} \mathrm{S} \\
99.972^{\circ} \mathrm{E}\end{array}$ & 25 & 7.2 \\
\hline 4 & $26-$ Feb-08 & $1: 06: 03$ & Kepulauan Mentawai & $\begin{array}{c}2.332^{\circ} \mathrm{S} \\
99.891^{\circ} \mathrm{E}\end{array}$ & 25 & 6.6 \\
\hline 5 & $26-$ Feb-08 & $4: 02: 18$ & Kepulauan Mentawai & $\begin{array}{c}2.245^{\circ} \mathrm{S} \\
99.808^{\circ} \mathrm{E}\end{array}$ & 25 & 6.7 \\
\hline 6 & $16-$ Apr-09 & $3: 01: 34$ & Kepulauan Mentawai & $\begin{array}{c}3.115^{\circ} \mathrm{S} \\
100.471^{\circ} \mathrm{E}\end{array}$ & 22 & 6.3 \\
\hline 7 & $16-$ Agu-09 & $14: 38: 21$ & Kepulauan Mentawai & $\begin{array}{c}1.479^{\circ} \mathrm{S} \\
99.490^{\circ} \mathrm{E}\end{array}$ & 20 & 6.7 \\
\hline 8 & $30-$ Sep-09 & $17: 16: 09$ & Padang & $\begin{array}{c}0.720^{\circ} \mathrm{S} \\
99.867^{\circ} \mathrm{E}\end{array}$ & 81 & 7.6 \\
\hline 9 & $01-$-Okt-09 & $8: 52: 27$ & $\begin{array}{c}\text { Sumatera Bagian } \\
\text { Selatan }\end{array}$ & $\begin{array}{c}2.482^{\circ} \mathrm{S} \\
101.524^{\circ} \mathrm{E}\end{array}$ & 9 & 6.6 \\
\hline
\end{tabular}




\begin{tabular}{|c|c|c|c|c|c|c|}
\hline No & Tanggal & $\begin{array}{c}\text { Waktu } \\
(\mathrm{UTC}+7)\end{array}$ & Lokasi & Koordinat & $\begin{array}{c}\text { Kedalaman } \\
(\mathrm{km})\end{array}$ & Magnitude \\
\hline 10 & 05-Mar-10 & $23: 07: 00$ & Kepulauan Mentawai & $\begin{array}{c}3.762^{\circ} \mathrm{S} \\
100.991^{\circ} \mathrm{E}\end{array}$ & 26 & 6.8 \\
\hline 11 & $07-$ Apr-10 & $5: 15: 01$ & $\begin{array}{c}\text { Sumatera Bagian } \\
\text { Utara }\end{array}$ & $\begin{array}{c}2.383^{\circ} \mathrm{N} \\
97.048^{\circ} \mathrm{E}\end{array}$ & 31 & 7.8 \\
\hline 12 & 05 -Mei-10 & $23: 29: 03$ & $\begin{array}{c}\text { Sumatera Bagian } \\
\text { Selatan }\end{array}$ & $\begin{array}{c}4.054^{\circ} \mathrm{S} \\
101.096^{\circ} \mathrm{E}\end{array}$ & 27 & 6.5 \\
\hline 13 & $09-$ Mei-10 & $12: 59: 41$ & $\begin{array}{c}\text { Sumatera Bagian } \\
\text { Utara }\end{array}$ & $\begin{array}{c}3.748^{\circ} \mathrm{N} \\
96.018^{\circ} \mathrm{E}\end{array}$ & 38 & 7.2 \\
\hline 14 & 25 -Okt-10 & $21: 42: 22$ & $\begin{array}{c}\text { Kepulauan Mentawai } \\
10.487^{\circ} \mathrm{S}\end{array}$ & 20.1 & 7.8 \\
\hline 15 & $06-$ Sep-11 & $0: 55: 11$ & $\begin{array}{c}\text { Sumatera Bagian } \\
\text { Utara }\end{array}$ & $\begin{array}{c}2.965^{\circ} \mathrm{N} \\
97.893^{\circ} \mathrm{E}\end{array}$ & 91 & 6.7 \\
\hline
\end{tabular}

Gempa bumi berkekuatan 9,1 Mw tanggal 26 Desember 2004 di lepas pantai barat Aceh, merupakan salah satu gempa terdahsyat dalam kurun waktu 40 tahun terakhir yang menghantam Asia. Gempa ini mengakibatkan terjadinya tsunami. Berdasarkan laporan Satkorlak PB (2005), jumlah korban meninggal akibat gempa bumi dan tsunami tahun 2004 di Provinsi Aceh mencapai 236.116 jiwa, Adapun Jumlah pengungsi sekitar 514.150 jiwa. tingkat kerusakan pada berbagai aspek (perumahan 34.000 unit, pendidikan 105 unit, kesehatan, agama) sebesar \$1,665 juta, infrastruktur (transportasi, komunikasi, energi, air, sanitasi, dan saluran irigasi) $\$ 877$ juta, produktif (pertanian, perikanan, industri, dan pertambangan) \$1,182 juta, lintas sektoral (lingkungan, pemerintahan, bank, dan keuangan) sebesar $\$ 652$ juta, dan lain sebagainya. Jumlah perkiraan kerugian berbagai sektor diperkirakan sebesar Rp. 43,5 trilyun atau U\$ 4,57 milyar. [5].

Dengan melihat begitu besarnya dampak gempa bumi bagi kerusakan lingkungan dan korban jiwa yang diakibatkannya, maka diperlukan kajian lebih dalam lagi untuk hal mitigasi bencana di Indonesia. Salah satu kajian yang diperlukan tersebut adalah studi deformasi dan geodinamika dari pergerakan lempeng tektonik. Dalam pengamatan suatu deformasi dilakukan survei deformasi dan geodinamika. Terdapat bermacam-macam metode dalam melakukan survei deformasi, seperti metode konvensional dengan menggunakan theodolit ataupun sipat datar. Dengan kemajuan teknologi, survei deformasi dan geodinamika juga dapat dilakukan dengan metode satelit, seperti dengan menggunakan Global Positioning System (GPS) [1]. GPS geodetik dipasang pada tempat yang dianggap mengalami pergeseran. Metode ini dapat mendokumentasikan dengan baik hampir semua tahapan yang terjadi dalam suatu siklus gempa bumi berikut besar dan arah pergeseran titik-titik dipermukaan bumi. Dengan demikian, deformasi yang terjadi dapat dipelajari dan dianalisis.

\section{METODOLOGI}

Penelitian ini secara umum dilakukan melalui beberapa tahapan diantaranya : penentuan lokasi pengamatan, pengumpulan data, pengolahan data, penyajian data serta analisis hasil pengolahan data.

\subsection{Lokasi Penelitian}

Lokasi penelitian berada di pulau Sumatera dengan sebaran data pengamatan SuGAr yang tersebar di pulau Sumatera. Berikut lokasi geografi wilayah penelitian (Gambar 2): 


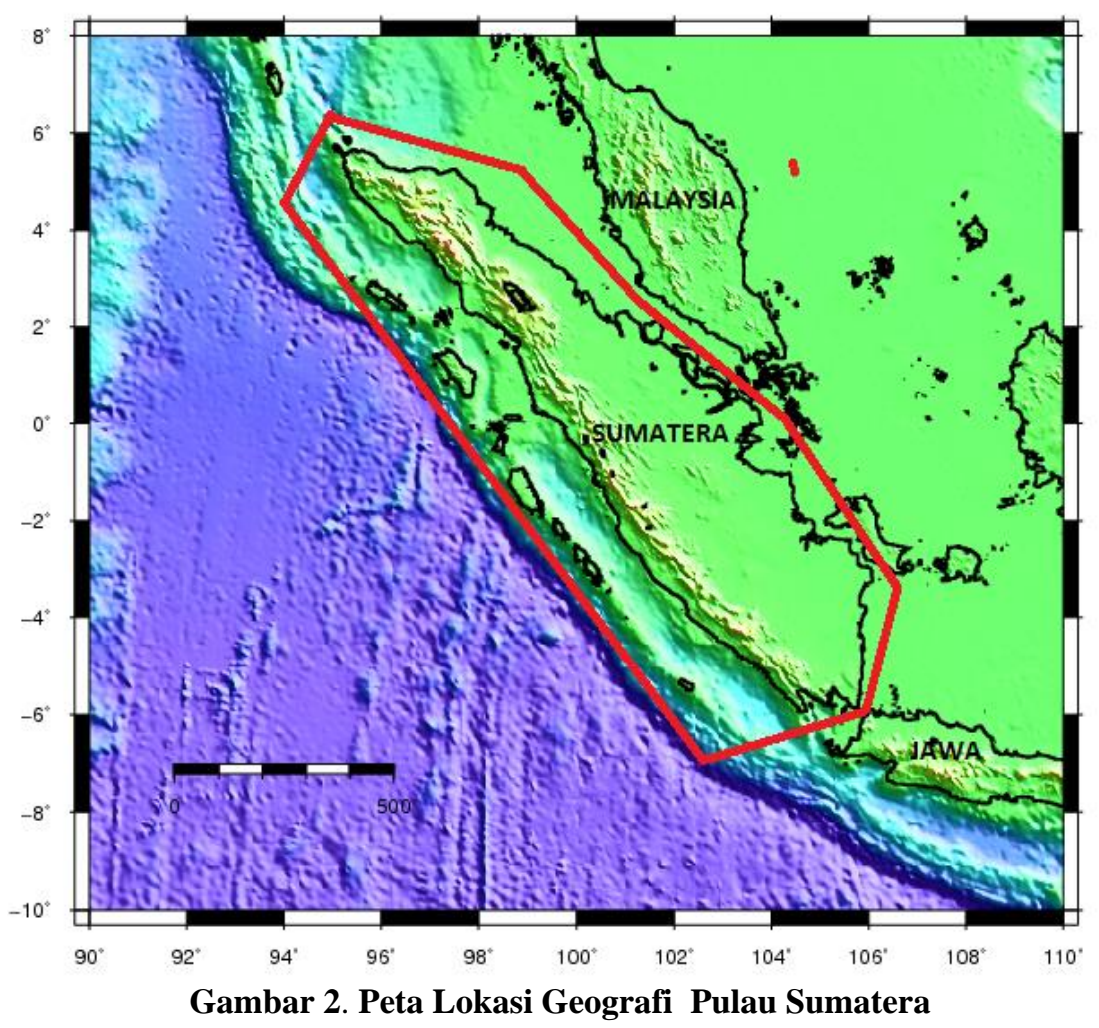

\subsection{Data}

Data pengamatan yang digunakan dalam penelitian ini adalah data GPS SuGAr (Sumatran GPS Array) dari tahun 2002 sampai 2008. Data diperoleh dengan cara mendownload dari website Sopac. Data pengamatan yang berhasil di download masih dalam bentuk terkompres (zip). Sampai tahun 2008 ada sekitar 28 stasiun SuGAr di daerah sepanjang pantai barat daya Pulau Sumatera. Berikut Peta sebaran stasiun pengamatan Sumatran GPS Array pada gambar 3 berikut ini:

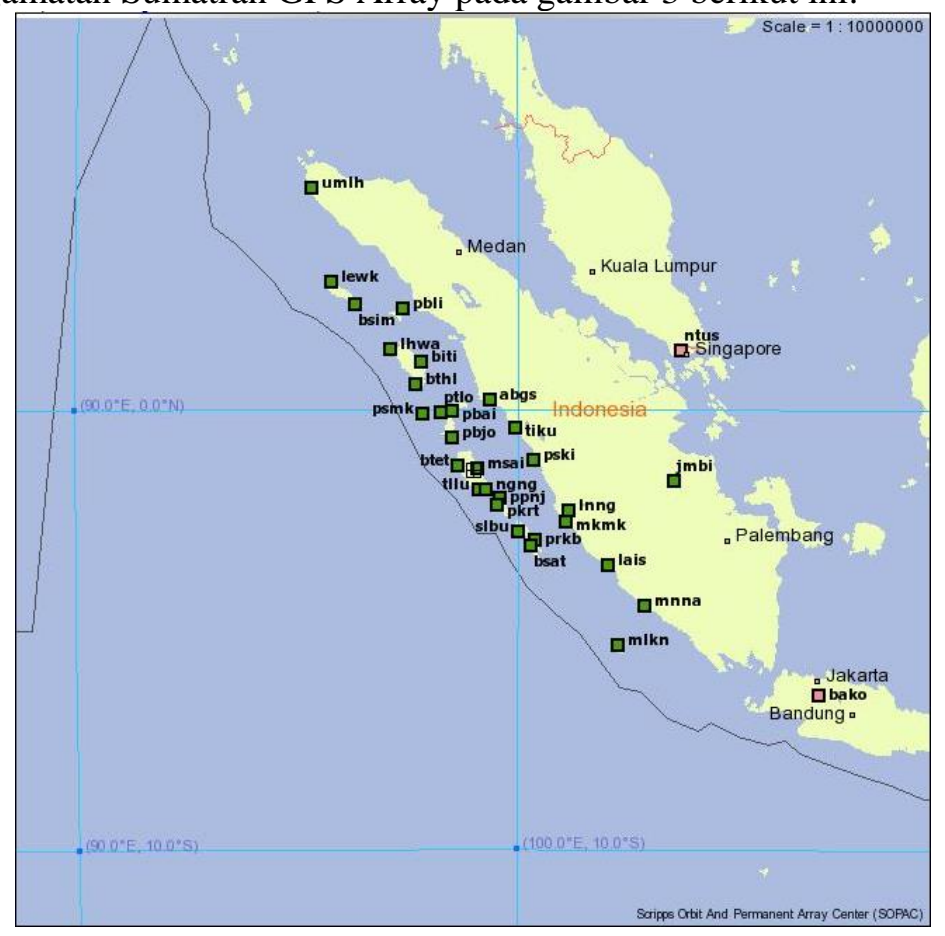

Gambar 3 Peta persebaran stasiun SuGAr di Indonesia [3] 
Selain dari data GPS SuGAr, data lain yang dibutuhkan adalah data titik ikat atau titik referensi. Untuk melakukan pengamatan koordinat suatu titik pengamatan diperlukan titik ikat atau titik acuan yang mengikat titik pengamatan sehingga dapat ditentukan bahwa titik pengamatan bergerak relatif terhadap titik referensi. Data titik ikat yang digunakan dalam penelitian ini adalah data titik ikat dari International GNSS Service (IGS) yang tersebar di sekitar titik pengamatan SuGAr. Data titik ikat IGS ini dikembangkan berdasarkan ITRF (International Terrestrial Reference Frame) 2008. Berikut ini adalah tabel List stasiun IGS yang dipakai pada pengolahan data tahun 2002-2008 pada tabel 2 .

Tabel 2 List Stasiun IGS Pengolahan Data SuGAr [4]

\begin{tabular}{|l|l|l|}
\hline ID Stasium & Lokasi & Negara \\
\hline \hline BAKO & Cibinong & Indonesia \\
\hline \hline CNMR & Saipan & USA \\
\hline COCO & Cocos (Keeling) Island & Australia \\
\hline CUSV & Patumwan & Thailand \\
\hline \hline DARW & Darwin & Australia \\
\hline DGAV & Diego Garcia Land & U.K. Territory \\
\hline \hline GUAM & Dededo & Guam \\
\hline \hline HYDE & Hyderabad & India \\
\hline \hline IISC & Bangalore & India \\
\hline \hline KIT3 & Kitab & Uzbekistan \\
\hline \hline KOUC & Koumac & New Caledonia \\
\hline KUNM & Kunming & China \\
\hline LAE1 & Lae & Papua New Guinea \\
\hline \hline SEY1 & La Misere & Seychelles \\
\hline \hline TNML & Hsinchu & China \\
\hline XMIS & Christmas Island & Australia \\
\hline \hline YAR2 & Dongara & Australia \\
\hline
\end{tabular}

\subsection{Metodologi Penelitian}

Untuk mengestimasi besarnya kecepatan vektor pergeseran masing-masing titik adalah dengan metode linier fit, yaitu memanfaatkan pendekatan fungsi linier. Sistem koordinat toposentrik lokal dipilih sebagai format data yang dipakai dalam proses hitungan linier fit untuk menghitung pola dan kecepatan pergeseran. Titik acuannya adalah sesi pertama pengamatan masing-masing stasiun, sehingga pergeseran titik yang sama pada sesi selanjutnya mengacu kepada pengamatan sesi pertama. Adapun fungsi liniernya dirumuskan sebagai berikut [6]:

$$
\mathrm{y}=\mathrm{ax}+\mathrm{b}
$$

di mana $\mathrm{x}$ adalah waktu pengamatan (tahun DOY / 365), y adalah data pada saat pengamatan sementara a dan b nilai-nilai yang ditentukan berdasarkan set data pengamatan. Dengan menggunakan metode persamaan kuadrat terkecil diperoleh nilai a dan b dimana a adalah vektor kecepatan pergeserannya sedangkan $b$ merupakan konstantanya.

Strain adalah analisis yang menunjukkan perubahan posisi, bentuk dan ukuran suatu objek dengan menggunakan data pengamatan langsung Geodetik yang diperoleh dari pengamatan langsung lapangan. Hubungan fungsional antara pergeseran dan parameter deformasi dalam Strain adalah sebagai berikut [6]:

$$
\varepsilon_{l}=\varepsilon_{e e} \cos ^{2} \theta+2 \varepsilon_{n e} \sin \theta \cos \theta+\varepsilon_{n n} \sin ^{2} \theta
$$




$$
\begin{aligned}
& \varepsilon_{2}=\varepsilon_{e e} \cos ^{2}\left(\theta+90^{\circ}\right)+2 \varepsilon_{n e} \sin \left(\theta+90^{\circ}\right) \cos \left(\theta+90^{\circ}\right)+\varepsilon_{n n} \sin ^{2}\left(\theta+90^{\circ}\right) \\
& \tan 2 \theta=\left(2 \varepsilon_{n e}\right) /\left(\varepsilon_{e e}-\varepsilon_{n n}\right)
\end{aligned}
$$

di mana $\varepsilon 1$ adalah kuantitas yang menunjukkan nilai perpanjangan dan $\varepsilon 2$ adalah kuantitas yang menunjukkan nilai kompresi.

Secara skematis metodologi penelitian ini dapat dilihat pada digram alir di bawah ini:

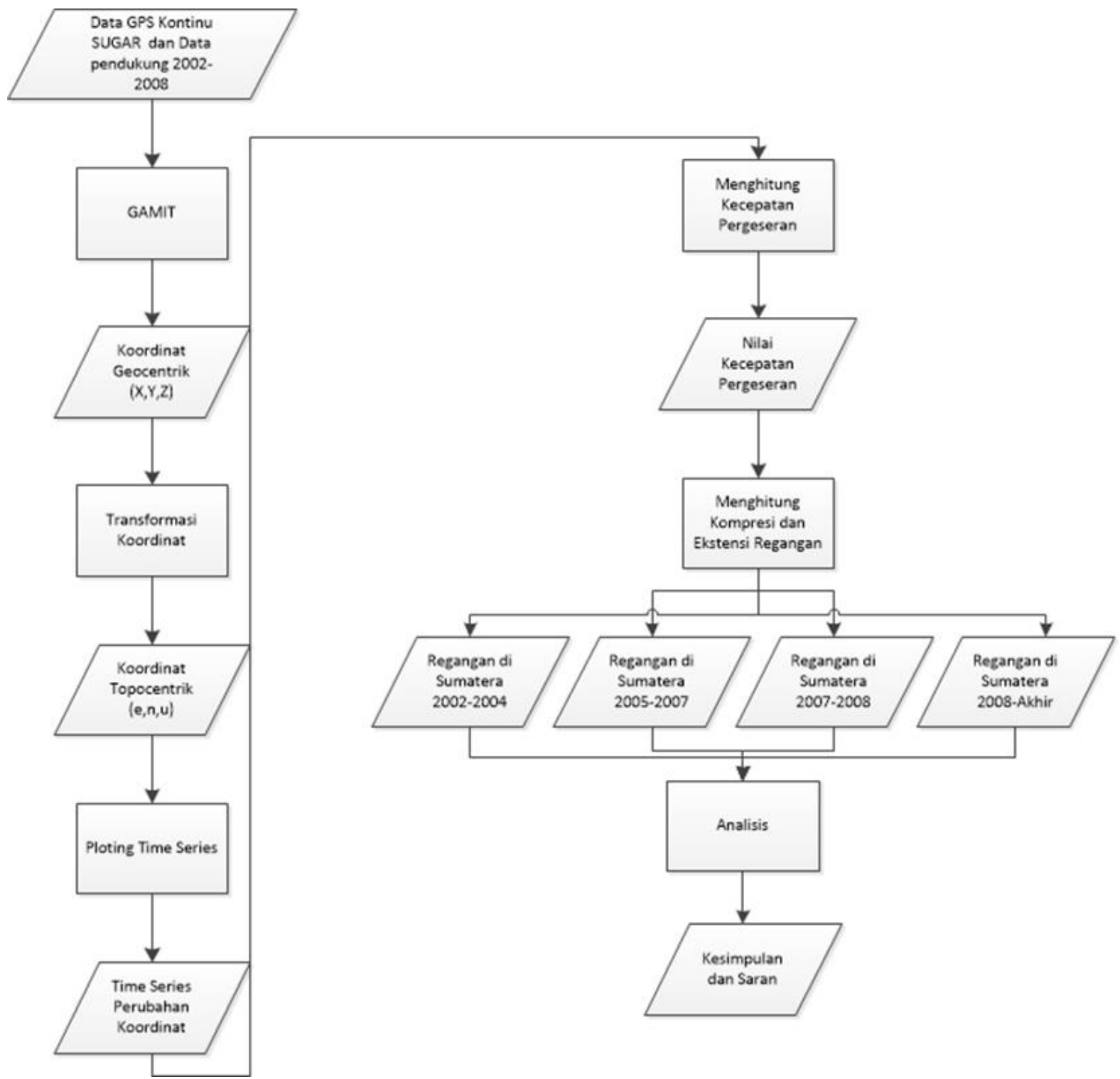

\section{HASIL DAN PEMBAHASAN}

Data GPS kontinuous SuGAr di download dari website Sopac, yang datanya dimulai dari hari ke 217 day tahun 2002, 2003, 2004, 2005, 2006, 2007 and 2008. International GNSS Service (IGS) menyediakan informasi navigasi (Broadcast Ephemeris data) dan informasi Orbit (Orbit files with SP3) yang di download dari website Sopac dan Cddis Nasa. Setelah melakukan konfigurasi untuk file control di Gamit 10.4, maka dilakukan pengolahan yang hasilnya adalah titik titik koordinat dan time series. Gambar 4. menunjukkan time series stasiun JMBI and NTUS,. Dari time series ini dapat dilihat 
terjadinya perubahan posisi dalam sumbu $\mathrm{x}, \mathrm{y}$ dan $\mathrm{z}$ saat terjadi gempa tahun 2004, 2005 dan 2007.Hal ini disebabkan oleh gempa yang terjadi tahun 2004 (Aceh), 2005 (Nias) and 2007 (Bengkulu).

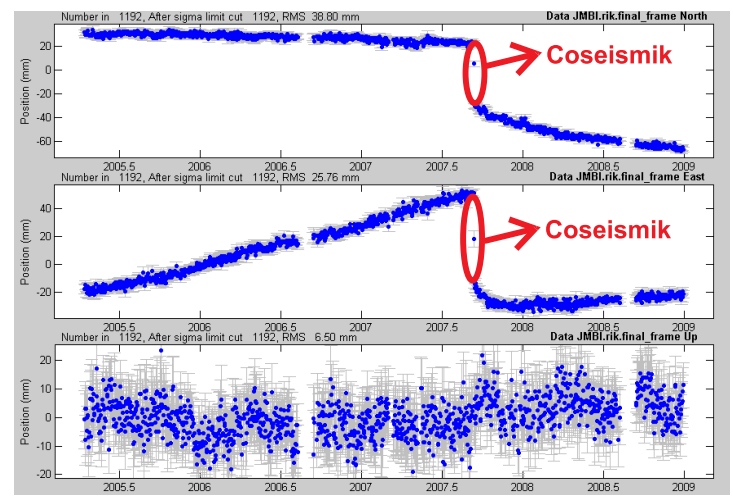

(a)

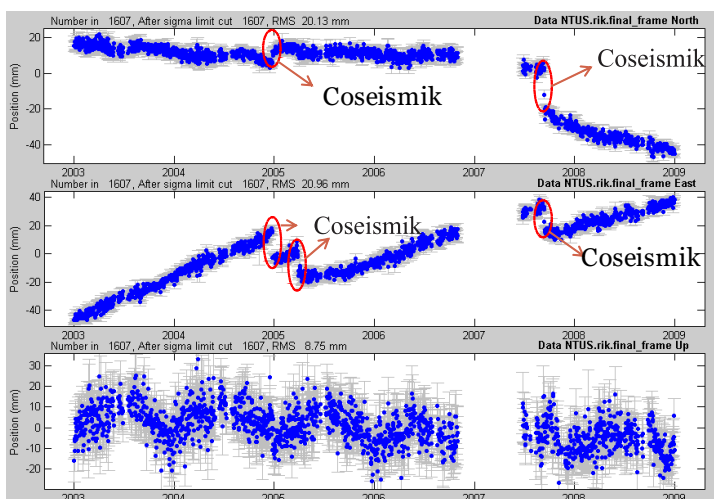

(b)

Gambar 4. (a) Time series stasiun JMBI (2006 - 2008); (b) Time series stasiun NTUS (2002-2008)

Gambar 4. (a) menunjukkan koseismik berlangsung pada bulan September 2007 di stasiun pengamatan JMBI terletak di Jambi. Stasiun ini dekat dari sumber Mentawai gempa di Bengkulu pada 12 September 2007. Terlihat ada pengaruh gempa pada time series stasiun JMBI yang menunjukkan perubahan dari posisi sebelumnya. Sementara Gambar 4. (b) menunjukkan co-seismic pada time series stasiun NTUS yang dipengaruhi gempa Aceh, Nias dan Bengkulu.

Nilai Perpindahan dari stasiun dapat digunakan jika data yang mengandung outlier telah terhapus. Dari koordinat perpindahan stasiun, dapat diperoleh vektor kecepatan semua stasiun. Berikut Ini adalah vektor kecepatan perpindahan posisi semua stasiun di 2 periode yaitu September 2002 - Desember 2004, dan Maret 2005 - September 2007.

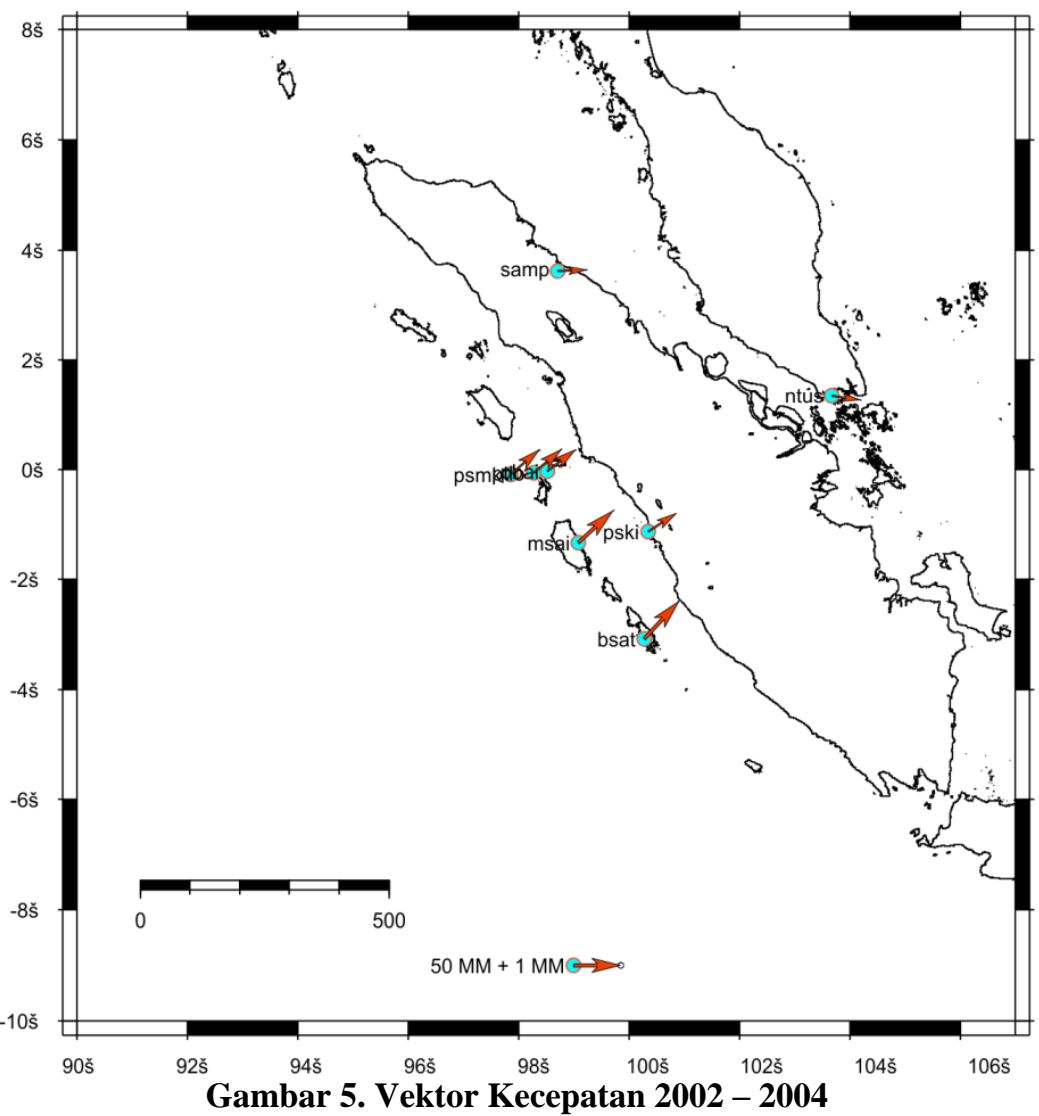

Rekayasa Hijau - 95 
Gambar 5 menunjukkan kecepatan vektor kecepatan periode 2002-2004 berkisar dari 30 sampai 60 $\mathrm{mm} /$ tahun dengan pergeseran arah menuju Timur Laut. Ini menunjukkan adanya akumulasi regangan / pengumpulan energy di sepanjang pulau Sumatera.

Gambar 6 di bawah ini menunjukkan bahwa ada beberapa stasiun pengamatan SuGAr yang arah pergeserannya berlawanan dengan arah pergerakan lempeng. Hal ini terjadi pada stasiun pengamatan terletak di bagian utara pulau Sumatera. Perubahan arah perpindahan dari stasiun pengamatan terletak di bagian utara pulau Sumatera, yang disebabkan oleh gempa bumi Aceh yang terjadi pada bulan Desember 2004 dan gempa bumi di Nias pada bulan Maret 2005. Hal ini menunjukkan terjadinya pelepasan energi yang disebabkan oleh gempa bumi. Untuk stasiun pengamatan di bagian Sumatera bagian tengah dan selatan, pergeseran arah vektor sesuai dengan arah gerakan lempeng. Hal ini menunjukkan proses kompresi atau terjadi proses pegumpulan energi.

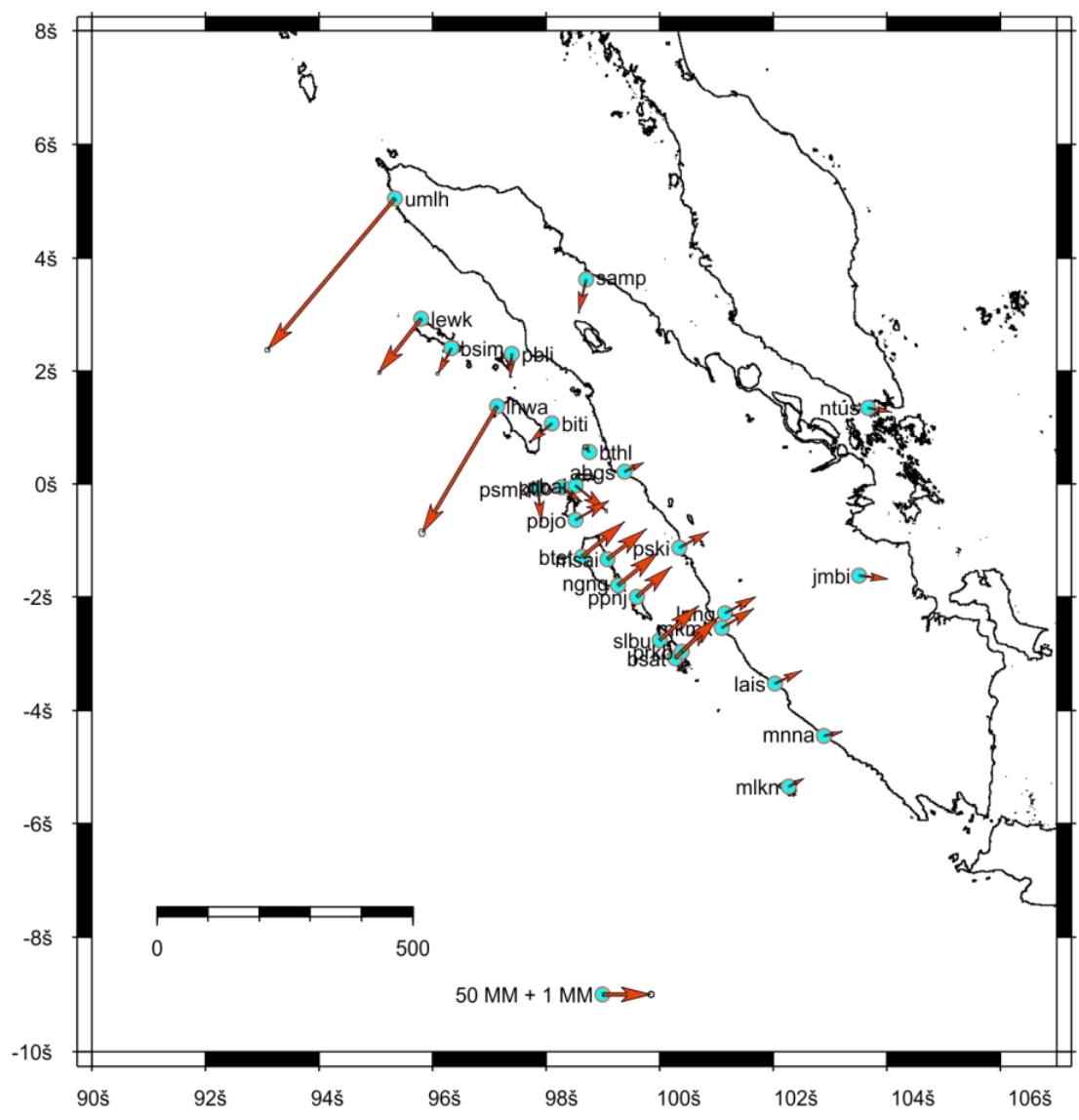

Gambar 6. Vektor Kecepatan 2005 - 2007

.Nilai regangan yang terjadi di sepanjang pulau Sumatera dapat diperkirakan dari vektor kecepatan dari 4 periode sebelumnya yaitu September 2002 - Desember 2004, Maret 2005 - September 2007, Oktober 2007 - Februari 2008, Maret 2008 sampai Desember 2008). Gambar 7 menunjukkan regangan di 4 periodeRegangan Periode 2002-2004, 2005-2007, 2007-2008, dan Maret 2008 sampai Desember 2008. 

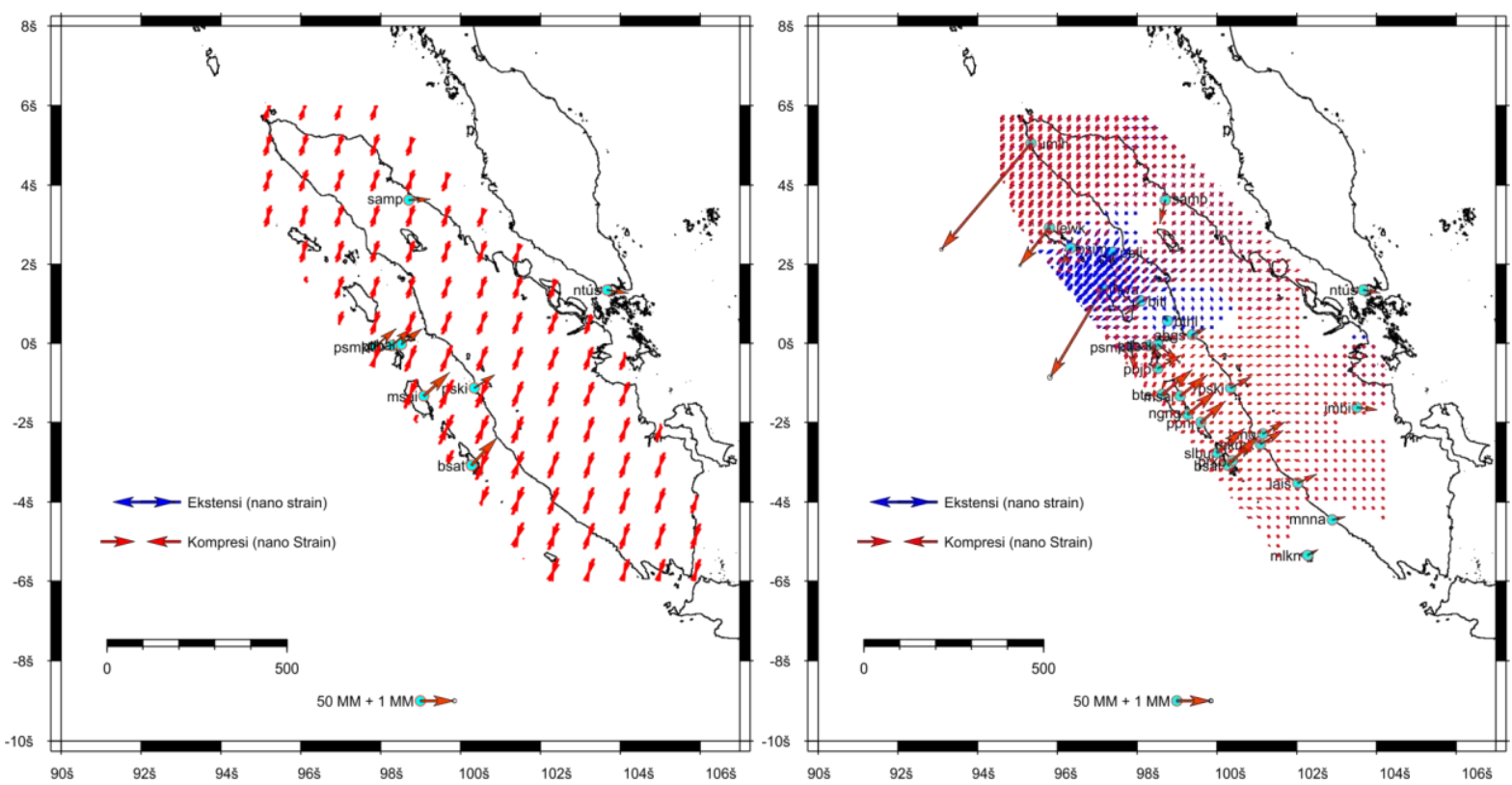

(a)

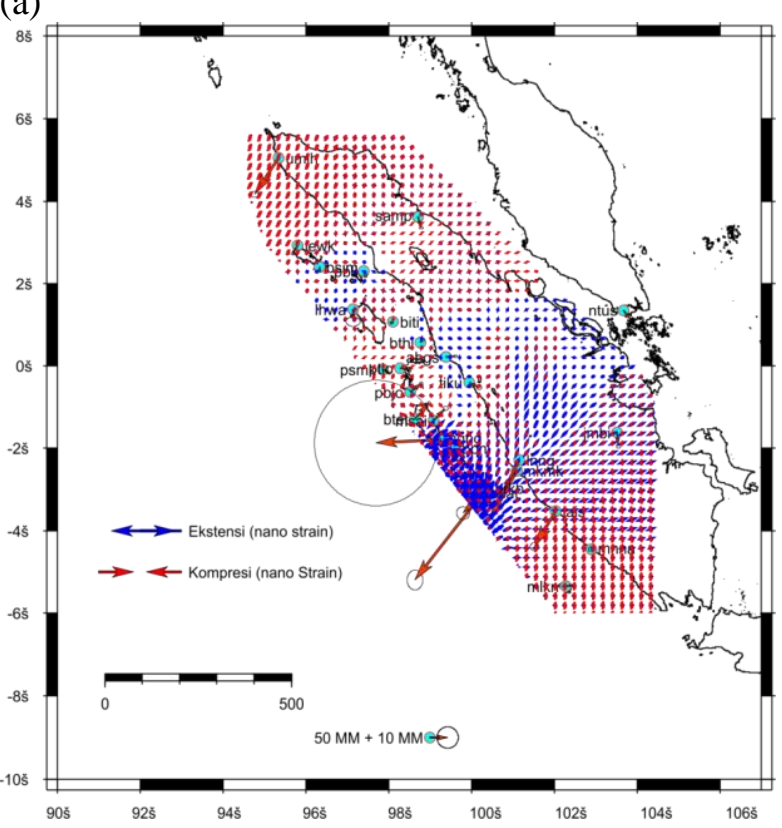

(c)

(b)

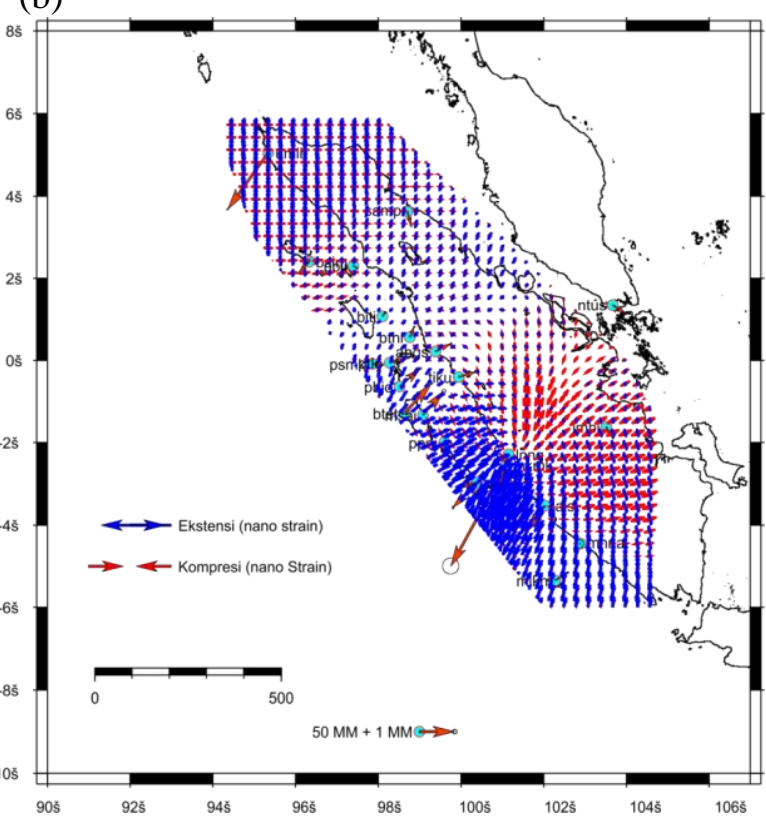

(d)

Gambar 7. (a) Regangan periode 2002-2004; (b) periode Regangan 2005-2007; (c) periode Regangan 2007 2008; (d) Regangan periode 2008 sampai akhir tahun 2008

Dalam penelitian ini, untuk memperkirakan akumulasi regangan, pulau Sumatera dibagi menjadi tiga segmen. Aceh dan Nias segmen, segmen Mentawai dan segmen Mentawai selatan. Gambar 8 . Menunjukkan akumulasi regangan periode 2002-2004. 

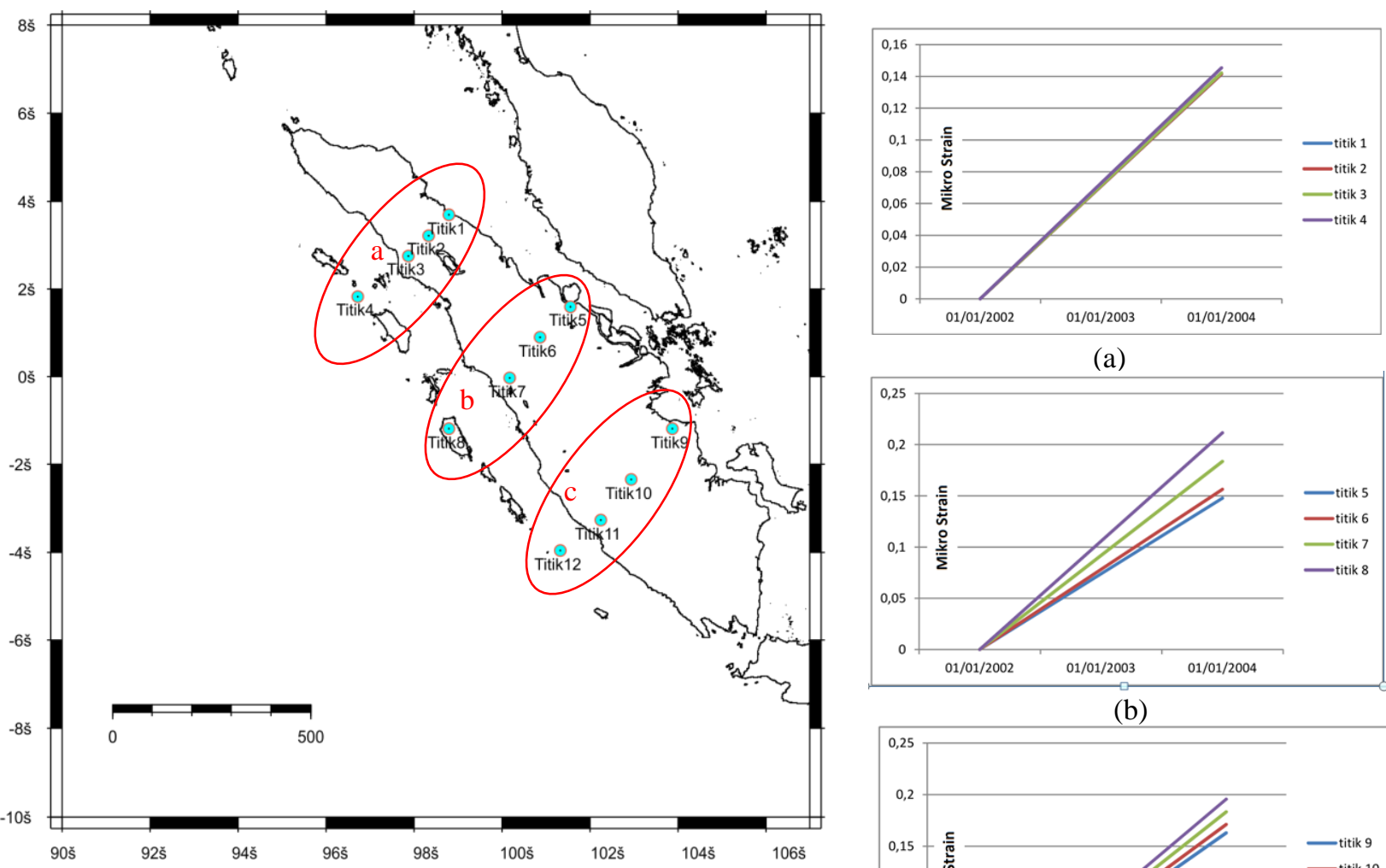

(a)

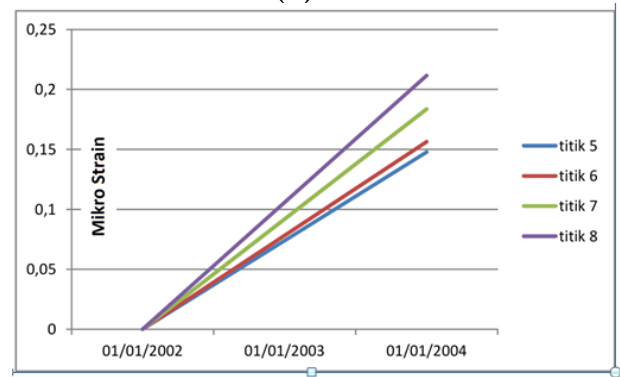

(b)

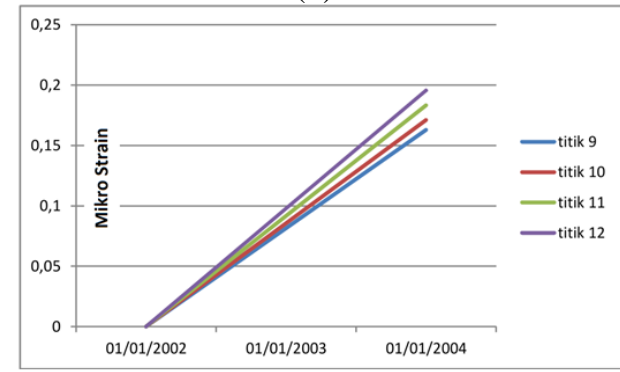

(c)

Gambar 8. (a) Akumulasi Regangan di segmen Aceh dan Nias periode 2002-2004; (b) Akumulasi Regangan di segmen Mentawai periode 2002-2004; (c) Akumulasi Regangan di Segmen Selatan (Segmen Mentawai) periode 2002-2004

Dampak yang ditimbulkan dari pelepasan regangan yang terjadi di Aceh 2004 dan Bengkulu 2007 mengakibatkan terjadinya gempa besar. Bahaya kerusakan lingkungan yang ditimbulkan oleh gempa lebih dahsyat dibandingkan dengan bencana alam lainnya. Pada saat gempa berlangsung terjadi beberapa peristiwa sebagai akibat langsung maupun tidak langsung, diantaranya:berbagai bangunan roboh, jalan menjadi putus, tanah longsor akibat guncangan, gempa yang terjadi di dasar laut dapat menyebabkan tsunami (gelombang pasang).

Berikut citra sebelum dan setelah gempa Aceh 2004 yang mengakibatkan gelombang Tsunami:
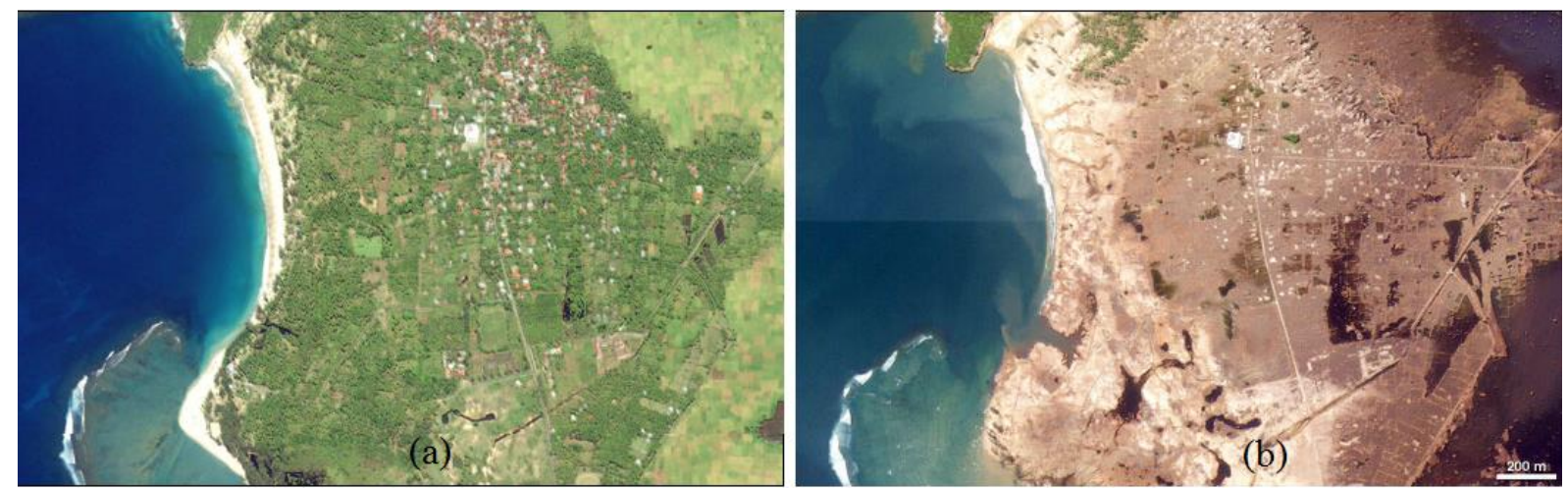

Gambar 9. Citra Nasa di Wilayah Loknga (a) Sebelum Tsunami Aceh (b) Setelah Tsunami Aceh 
Dari gambar 9 hasil Citra Nasa secara visual dapat dilihat terjadinya kerusakan lingkungan akibat gempa yang menimbulkan tsunami di wilayah Loknga, Aceh. Adapun kerusakan lingkungan yang terjadi baik ekosistem alam maupun ekosistem buatan manusia seperti terkikisnya pantai, kerusakan pohon, hancurnya gedung, perumahan, jembatan, jalan, sarana prasarana pemerintahan dan lainnya. Oleh karena itu, dengan mempelajari trend akumulasi strain, dapat dilihat wilayahyang berpotensi gempa baik yang menimbulkan tsunami ataupun tidak, sehingga dapat dilakukan mitigasi agar dampak yang diakibatkan setelah terjadinya gempa maupun tsunami dapat di minimalisir.

\section{SIMPULAN}

Vektor perpindahan dari 6 stasiun pengamatan SuGAr sebelum terjadinya gempa mengarah ke timur laut dengan kecepatan 3-5 cm / tahun. Hal ini menunjukkan terjadinya proses interseismik sebelum gempa Aceh, Desember 2004. Setelah terjadi gempa Aceh Desember 2004, ada perbedaan arah vector perpindahan pada periode tahun 2005-2007 dengan arah berlawanan dengan arah pergerakan lempeng tektonik di stasiun yang terletak di bagian utara pulau Sumatera. Sementara di stasiun pengamatan, terletak di Selatan Sumatera perpindahan arah vektor sesuai dengan pergerakan lempeng. Dan untuk periode 2007-2008 dan 2008 sampai akhir tahun 2008, vektor perpindahan stasiun yang terletak di bagian selatan pulau Sumatera berlawanan dengan arah pergerakan lempeng tektonik. Hal ini disebabkan oleh gempa bumi September 2007. Sedangkan bagian tengah Sumatera memiliki potensi untuk terjadinya gempa bumi berikutnya. Hal ini dapat dilihat dari akumulasi regangan dengan vektor kecepatan gerakan arah yang sama dari Indo-Australia. Hasil pengolahan data didapat Kecepatan akumulasi regangan di sekitar Sumatera adalah sekitar 0,1 regangan mikro per tahun. Selain itu, dampak kerusakan lingkungan akibat gempa Aceh dan Bengkulu menyebabkan berbagai bangunan runtuh, jalan menjadi putus, dan timbulnya tsunami pada gempa Aceh 2004.

\section{DAFTAR PUSTAKA}

[1] Abidin, Hasanuddin.Z. 2007. Penentuan Posisi dengan GPS dan Aplikasinya. PT Pradnya Paramita, Jakarta.

[2] Bock, Y., L.Prawirodirdjo, J. F. Genrich, C. W. Stevens, R. McCaffrey, C. Subarya, S. S. O. Puntodewo, and E. Calais, (2003). Crustral motion in Indonesia from Global Positioning System Measurements, Journal of Geophysical Research-Solid Earth. 108..

[3] Data SuGAr . 2002 - 2008. http://sopac.ucsd.edu/dataBrowser.shtml, diakses tanggal 8 Januari 2017.

[4] IGS Network.2010. Adress : http://igs.cb.jpl.nasa.gov/network.refframe.html diakses tanggal 9 Januari 2017

[5] Rino, 2010. Regangan Tektonik Berdasarkan Pengamatan Kontinu Sumatran GPS Array (SuGAr) Tahun 2007-2008. Tugas Akhir Program Studi Teknik Geodesi dan Geomatika Institut Teknologi Bandung (ITB), Bandung.

[6] Scholz, C.H. (2002) The Mechanics of Earthquakes and Faulting. Cambridge University, Cambridge.

[7] United States Geological Survey. 2002-2008. https://earthquake.usgs.gov/earthquakes/search/, diakses tanggal 3 Januari : 2017. 